\title{
QUANTITATIVE MORPHOMETRIC ANALYSIS OF KOLAR TALUK WATERSHED USING RS AND GIS TECHNIQUES
}

\author{
Chalapathi K $^{1 *}$, Dr.M. Inayathulla ${ }^{2}$ \\ Research Scholar, Department of Civil Engineering, UVCE, Bangalore-560056.Karnataka, India ${ }^{1}$ \\ Professor, Department of Civil Engineering, UVCE, Bangalore-560056.Karnataka, India ${ }^{2}$
}

\begin{abstract}
The quantitative analysis of morphometric parameters is found to be of immense utility in river basin evaluation, watershed prioritization for soil and water conservation and natural resources management at watershed level. The study area chosen was Kolar Taluk Sub watersheds, Kolar District since it was found in the rocks and granite area of Karnataka state, India. The study area covers an area of $793.20 \mathrm{~km} 2$ and comprise of 24 sub watersheds. In the present this study morphometric analysis of Kolar Taluk watershed is carried out at sub watershed level using GIS which is a suitable tool to study the morphological analysis. The watershed is divided into 24 sub watersheds based on topography and drainage pattern. The analysis is carried out through measurement of linear, aerial and relief aspects of watershed. The morphometric parameters are useful in understanding the hydrological processes of the drainage basin.
\end{abstract}

Keywords: Sub Watersheds, Morphometric Parameters, RS and GIS Techniques,

\subsection{INTRODUCTION}

Watershed is a natural hydrological entity from which runoff resulting from precipitation flows past a single point into large stream, river, lake or ocean. Morphometric analysis provides quantitative description of the basin geometry to understand initial slope or inequalities in the rock hardness, structural controls, recent diastrophism, geological and geomorphic history of drainage basin. Geographical Information System (GIS) techniques are now a days used for assessing various terrain and morphometric parameters of the drainage basins and watersheds, as they provide a flexible environment and a powerful tool for the manipulation and analysis of spatial information.

\subsection{STUDY AREA DETAILS}

The study area chosen was Kolar Taluk Sub watersheds, Kolar District. The study area geographically lies between North latitude $12^{\circ} 46^{\prime}$ to $13^{\circ} 58^{\prime}$ and East Longitude $77^{\circ} 21^{\prime}$ to $78^{\circ} 35^{\prime}$. The watershed area geographically covers an area of 793.20 Sq. km. The types of soils distributed range from red loamy soil to red sandy soil and lateritic soil. The topography of the district is undulating to plain. The central and eastern parts of the district forming the valley of Palar Basin, are well cultivated. The present study is intended to classify the land for its best suitability based on the various parameters which are derived from Survey of India (SOI) Toposheet $57 \mathrm{~K} / 4,57 \mathrm{~K} / 8,57 \mathrm{~K} / 3,57 \mathrm{G} / 15$ and $57 \mathrm{G} / 16$ on 1:50,000 scale. 


\section{International Advanced Research Journal in Science, Engineering and Technology \\ Impact Factor 7.105 ㄷ Vol. 9, Issue 1, January 2022 \\ DOI: 10.17148/IARJSET.2022.9113}



Fig.1 The Location of watershed in the study area

\subsection{METHODOLOGY}

In the present study morphometric analysis of the basin is carried out at sub watershed level using GIS techniques. The survey of India Toposheet numbers $57 \mathrm{~K} / 4,57 \mathrm{~K} / 8,57 \mathrm{~K} / 3,57 \mathrm{G} / 15$ and $57 \mathrm{G} / 16$ on the scale of 1: 50,000 were used in study of different morphometric parameters and for preparation of different maps like Location Map, Drainage Map, etc. Stream ordering has been done in the watershed according Strahler hierarchical order. The different morphometric parameters have been calculated by using standard formulae. The parameters like basin area, length and perimeter of the basin etc., are calculated by using Arc GIS tool.

\subsection{RESULTS AND DISCUSSIONS}

\subsection{Stream order:}

For drainage basin analysis, the first step is to assign the stream orders. In the present study, ranking of streams has been carried out based on the method proposed by Strahler. According to Strahler's method of ordering, the highest stream order obtained is $6^{\text {th }}$ order and hence designated as $6^{\text {th }}$ order watershed.

\subsection{Stream length:}

The length of the stream is an indication of the steepness of the drainage basin as well as the degree of drainage. The stream length has been computed based on stream ordering for all the sub watersheds. Generally, the total length of stream segments is maximum in first order and decreases as the stream order increases. 


\section{International Advanced Research Journal in Science, Engineering and Technology \\ Impact Factor 7.105 ㄷ Vol. 9, Issue 1, January 2022 \\ DOI: 10.17148/IARJSET.2022.9113}

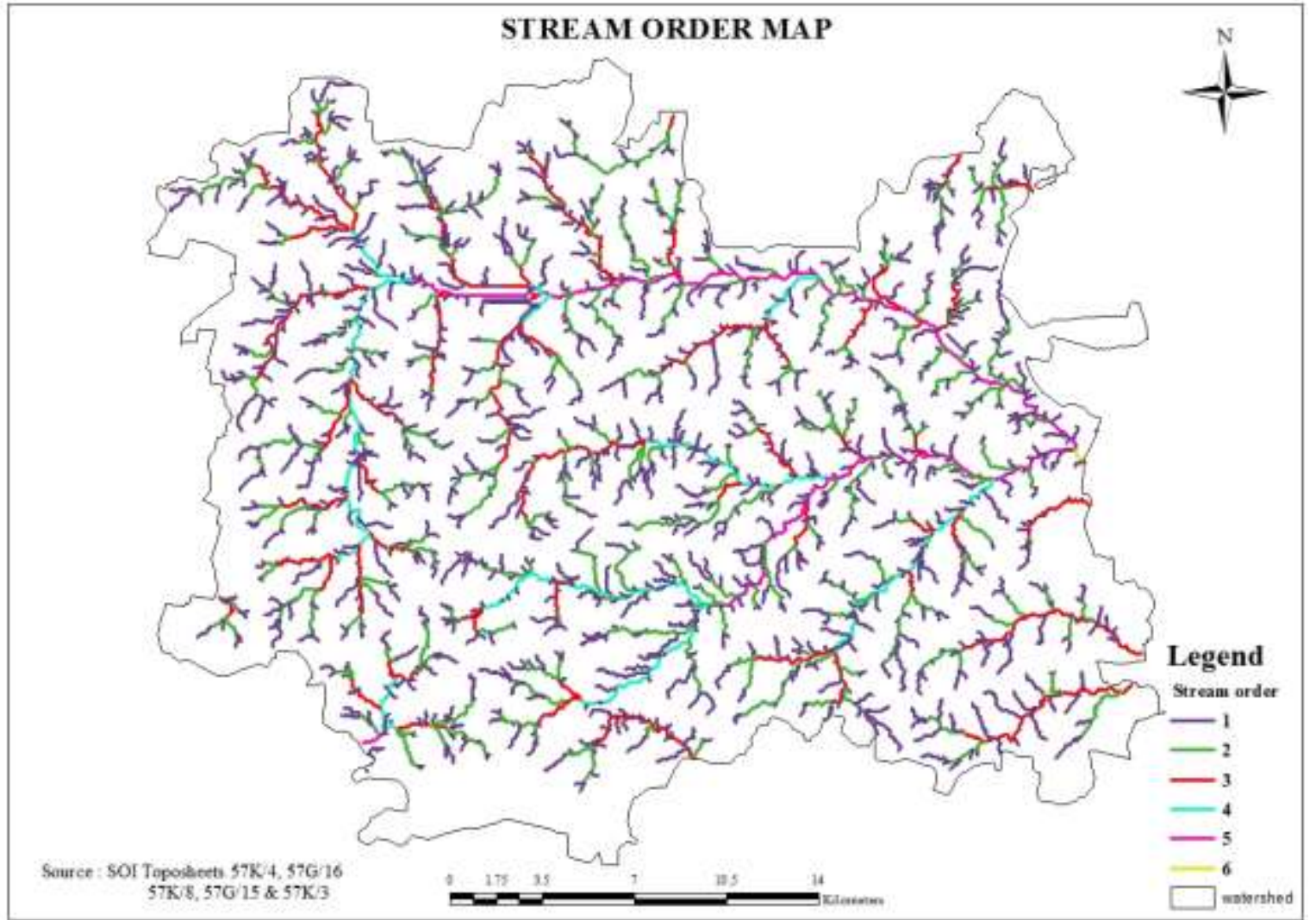

Fig. 2 Stream order map of the study

\subsection{Bifurcation ratio:}

The term bifurcation ratio $(\mathrm{Rb})$ may be defined as the ratio of the number of the stream segments $\mathrm{N}_{\mathrm{u}}$ of given order to the number of segments of the next higher order $\mathrm{N}_{(\mathrm{u}+1)}$. In the present study the values of $\mathrm{R}_{\mathrm{b}}$ varies from 2.79 to 5.76 for the sub watersheds and for the sub watersheds 21 and 22 the bifurcation ratio is more than 5 hence it shows there is a geological disturbance.

\subsection{Mean stream length:}

Mean stream length calculated by dividing the total stream length of order ( $u$ ) by the number of streams of segments in that order.

It is observed that the mean stream length of any given order is greater than that of the lower order but less than that of the next higher order.

\subsection{Drainage density:}

Drainage density $\left(D_{d}\right)$ is one of the important indications of the linear scale of landform elements in stream eroded topography. It is defined as the total stream length to the total area of watershed. The drainage density of the area varies from 0.69 to $2.22 \mathrm{~km} / \mathrm{sq} . \mathrm{km}$ indicating that the sub watersheds are very coarse to coarse textured.

\subsection{Stream frequency:}

The values of stream frequency for 24 watersheds exhibits positive correlation with the drainage density values of the area indicating the increase in stream population with respect to increase in drainage density.

\subsection{Circularity ratio:}

The circulatory ratio is mainly concerned with the length and frequency of streams, geological structures, land use/land cover, climate, relief and slope of the basin. It is the ratio of the area of the watersheds to the area of circle having the same circumference as the perimeter of the watershed. The circularity ratio varies from 0.28 to 0.69 for the watersheds. Its low, medium and high values are correlated with youth, mature and old stage of the cycle of the tributaries in sub watershed of the region. 


\section{International Advanced Research Journal in Science, Engineering and Technology \\ Impact Factor 7.105 ㄷ Vol. 9, Issue 1, January 2022 \\ DOI: 10.17148/IARJSET.2022.9113}

4.8 Watershed shape factor:

Watershed shape is the shape of projected surface on the horizontal plane of watershed map. The shape of the drainage basin also governs the rate at which water enters the stream. The quantitative expression of watershed can be characterized by form factor, compaction coefficient, circularity ratio, and elongation ratio.

4.9 Form factor:

Form factor may be defined as the ratio of the area of the watershed and square of the watershed length.

\subsection{Compactness coefficient:}

Compactness coefficient of a watershed is the ratio of perimeter of watershed to circumference of circular area, which equals the area of the watershed. Compactness coefficient is used to express the relationship of a hydrologic watershed with that of a circular watershed having the same area as the hydrologic watershed.

\subsection{Constant of channel maintenance}

The inverse of drainage density is the constant of channel maintenance. It indicates the number of Sq.km of watershed required to sustain one linear $\mathrm{km}$ of channel and expressed as Sq. $\mathrm{km} / \mathrm{km}$.

\subsection{Length of over land flow:}

Length of overland flow is the flow of water over the surface before it becomes concentrated in definite stream channels. The length of overland flow is a measure of erodibility, and is one of the independent variable affecting both the hydrologic and physiographic development of the drainage basin.

\subsection{Elongation ratio:}

Elongation ratio $\left(\mathrm{R}_{\mathrm{e}}\right)$ defined as the ratio of diameter of a circle of the same area as the watershed to the maximum watershed length. It is a very significant index in the analysis of watershed shape which helps to give an idea about the hydrological character of a drainage basin. The elongation ratio ranges from 0.38 to 1.0 which indicates that the watershed is elongated to circular.

\subsection{Watershed relief:}

Difference in the elevation between the highest point of a watershed and the lowest point on the valley floor is known as the total relief of the river watershed. The values of relief vary from $920 \mathrm{~m}$ to $720 \mathrm{~m}$ indicates that the watershed has enough slope for the runoff to occur from the remote point of the watershed to mouth.

\subsection{Relief ratio:}

The elevation difference between the highest and lowest points on the valley floor of a sub watershed is known as the total relief of that sub watershed. The relative relief ratios are ranging from 0 to 0.001 . The higher relative relief indicates that it is composed of resistant rock patches and lower relief ratio indicates less resistant patch of rocks.

Table 1. Sub watershed wise morphometric characteristics of Kolar taluk watershed

\begin{tabular}{|c|c|c|c|c|c|c|c|c|c|c|c|c|c|c|c|}
\hline \multirow{2}{*}{$\begin{array}{l}\text { WS } \\
\text { No }\end{array}$} & \multirow{2}{*}{$\begin{array}{l}\text { Area } \\
(\mathrm{Sq} . \mathrm{km})\end{array}$} & \multirow{2}{*}{$\begin{array}{l}\text { Perimeter } \\
(\mathrm{km})\end{array}$} & \multirow{2}{*}{$\begin{array}{l}\text { Highest } \\
\text { stream } \\
\text { order }\end{array}$} & & \multicolumn{5}{|c|}{ Stream Order } & \multicolumn{6}{|c|}{ Stream Length $(\mathrm{km})$} \\
\hline & & & & 1 & 2 & 3 & 4 & 5 & 6 & 1 & 2 & 3 & 4 & 5 & 6 \\
\hline 1 & 9.98 & 13.52 & 3 & 11 & 3 & 1 & - & - & - & 3.4 & 2.27 & 1.27 & - & - & - \\
\hline 2 & 22.37 & 25.12 & 4 & 40 & 9 & 3 & 1 & - & - & 16.37 & 9.09 & 7.7 & 1.4 & - & - \\
\hline 3 & 52.02 & 36.09 & 4 & 83 & 19 & 5 & 1 & - & - & 40.81 & 20.16 & 13.35 & 8.2 & - & - \\
\hline 4 & 40.44 & 37.30 & 5 & 54 & 14 & 5 & 2 & 1 & - & 22.55 & 14.36 & 6.11 & 3.22 & 0.96 & - \\
\hline 5 & 42.39 & 38.03 & 5 & 70 & 10 & 2 & 2 & 1 & - & 40.74 & 10.28 & 7.2 & 9.07 & 0.07 & - \\
\hline 6 & 37.27 & 32.08 & 4 & 57 & 13 & 3 & 1 & - & - & 28.58 & 11.19 & 13.81 & 0.17 & - & - \\
\hline 7 & 71.47 & 50.91 & 5 & 121 & 26 & 6 & 2 & 1 & - & 64.31 & 28.29 & 21.54 & 2.46 & 6.05 & - \\
\hline 8 & 14.43 & 17.99 & 4 & 30 & 7 & 2 & 1 & - & - & 11.93 & 5.61 & 1.95 & 2.87 & - & - \\
\hline 9 & 16.84 & 22.24 & 4 & 22 & 5 & 2 & 1 & - & - & 11.41 & 7.69 & 3.55 & 0.05 & - & - \\
\hline 10 & 40.21 & 31.57 & 4 & 72 & 18 & 3 & 1 & - & - & 40.49 & 19.08 & 9.16 & 4.85 & - & - \\
\hline 11 & 38.38 & 32.31 & 5 & 62 & 11 & 1 & 2 & 1 & - & 36.99 & 14.98 & 1.59 & 16.2 & 0.03 & - \\
\hline 12 & 42.69 & 39.71 & 5 & 67 & 15 & 2 & - & 1 & - & 29.6 & 18.62 & 9.81 & - & 5.58 & - \\
\hline 13 & 28.05 & 27.16 & 3 & 28 & 5 & 1 & - & - & - & 13.57 & 4.26 & 6.2 & - & - & - \\
\hline 14 & 15.57 & 22.48 & 3 & 12 & 2 & 1 & - & - & - & 4.13 & 6.74 & 0.67 & - & - & - \\
\hline 15 & 32.83 & 34.82 & 5 & 62 & 18 & 3 & 1 & 1 & - & 32.35 & 13.47 & 5.04 & 3.72 & 8.27 & - \\
\hline 16 & 38.37 & 34.41 & 5 & 61 & 13 & 2 & 1 & 1 & - & 32.63 & 12.18 & 7.02 & 3.14 & 5.94 & - \\
\hline
\end{tabular}


International Advanced Research Journal in Science, Engineering and Technology

Impact Factor 7.105 ㄷ Vol. 9, Issue 1, January 2022

DOI: 10.17148/IARJSET.2022.9113

\begin{tabular}{|l|l|l|l|l|l|l|l|l|l|l|l|l|l|l|l|}
\hline 17 & 23.60 & 28.36 & 4 & 36 & 10 & 2 & 1 & - & - & 18.56 & 11.56 & 6.09 & 0.04 & - & - \\
\hline 18 & 67.02 & 44.85 & 5 & 122 & 23 & 6 & 1 & 1 & - & 56.78 & 31.1 & 7.05 & 10.62 & 7.57 & - \\
\hline 19 & 8.12 & 14.75 & 3 & 14 & 3 & 1 & - & - & - & 5.69 & 2.73 & 1.56 & - & - & - \\
\hline 20 & 14.84 & 22.34 & 3 & 16 & 5 & 1 & - & - & - & 8.44 & 5.41 & 1.79 & - & - & - \\
\hline 21 & 31.97 & 32.94 & 3 & 32 & 7 & 1 & - & - & - & 21.98 & 8.15 & 8.75 & - & - & - \\
\hline 22 & 29.05 & 30.94 & 3 & 37 & 8 & 1 & - & - & - & 18.13 & 8.26 & 8.85 & - & - & - \\
\hline 23 & 9.95 & 15.97 & 3 & 9 & 2 & 1 & - & - & - & 3.08 & 0.55 & 3.46 & - & - & - \\
\hline 24 & 67.52 & 55.41 & 6 & 119 & 25 & 6 & - & 2 & 1 & 48.7 & 30.32 & 8.06 & - & 17.44 & 0.55 \\
\hline
\end{tabular}

Table 2. Sub watershed wise morphometric characteristics of Kolar taluk watershed

\begin{tabular}{|c|c|c|c|c|c|c|c|c|c|c|c|c|c|}
\hline $\begin{array}{l}\text { WS } \\
\text { No }\end{array}$ & $\begin{array}{c}\text { Mean } \\
\text { Bifurcation } \\
\text { Ratio } \\
\left(\mathrm{R}_{\mathrm{bm}}\right)\end{array}$ & $\begin{array}{l}\text { Stream } \\
\text { Length } \\
\text { Ratio } \\
\left(\mathrm{R}_{\mathrm{l}}\right)\end{array}$ & $\begin{array}{l}\text { Drainage } \\
\text { density } \\
\left(D_{d}\right)\end{array}$ & $\begin{array}{c}\text { Stream } \\
\text { frequency }\end{array}$ & $\begin{array}{c}\text { Length } \\
(\mathrm{km})\end{array}$ & $\begin{array}{l}\text { Width } \\
(\mathrm{km})\end{array}$ & $\begin{array}{l}\text { Elongation } \\
\text { Ratio }\left(\mathrm{R}_{\mathrm{e}}\right)\end{array}$ & $\begin{array}{l}\text { Circularity } \\
\text { Ratio }\left(\mathrm{R}_{\mathrm{c}}\right)\end{array}$ & $\begin{array}{l}\text { Form } \\
\text { Factor } \\
\left(\mathrm{R}_{\mathrm{f}}\right)\end{array}$ & $\begin{array}{l}\text { Max. } \\
\text { Relief } \\
(\mathrm{km})\end{array}$ & $\begin{array}{c}\text { Relief } \\
\text { Ratio } \\
(\mathrm{m})\end{array}$ & $\begin{array}{c}\text { Relative } \\
\text { Relief } \\
\left(\mathrm{R}_{\mathrm{hp}}\right)\end{array}$ & $\begin{array}{c}\text { Ruggedness } \\
\text { Number } \\
\text { (Rn) }\end{array}$ \\
\hline 1 & 3.33 & 2.06 & 0.69 & 1.50 & 3.07 & 4.03 & 0.65 & 0.69 & 1.06 & 0.02 & 0.006 & 0.001 & 0.0001 \\
\hline 2 & 3.48 & 1.85 & 1.54 & 2.37 & 5.94 & 5.58 & 0.51 & 0.45 & 0.63 & 0.04 & 0.006 & 0.001 & 0.0006 \\
\hline 3 & 4.39 & 2.58 & 1.59 & 2.08 & 6.40 & 8.51 & 0.72 & 0.50 & 1.27 & 0.04 & 0.006 & 0.001 & 0.0006 \\
\hline 4 & 2.79 & 1.39 & 1.17 & 1.88 & 5.45 & 7.58 & 0.74 & 0.37 & 1.36 & 0.02 & 0.003 & 0.000 & 0.0002 \\
\hline 5 & 3.75 & 1.64 & 1.59 & 2.01 & 8.59 & 5.36 & 0.48 & 0.37 & 0.57 & 0.02 & 0.002 & 0.000 & 0.0003 \\
\hline 6 & 3.91 & 2.37 & 1.44 & 1.99 & 5.53 & 7.28 & 0.70 & 0.46 & 1.22 & 0.02 & 0.003 & 0.000 & 0.0003 \\
\hline 7 & 3.50 & 2.65 & 1.72 & 2.20 & 5.82 & 12.17 & 0.92 & 0.35 & 2.11 & 0.02 & 0.003 & 0.000 & 0.0003 \\
\hline 8 & 3.26 & 2.06 & 1.55 & 2.77 & 4.34 & 4.30 & 0.56 & 0.56 & 0.77 & 0.02 & 0.004 & 0.001 & 0.0003 \\
\hline 9 & 2.97 & 1.38 & 1.35 & 1.78 & 3.78 & 4.43 & 0.69 & 0.43 & 1.18 & 0.02 & 0.005 & 0.000 & 0.0003 \\
\hline 10 & 4.33 & 2.12 & 1.83 & 2.34 & 10.62 & 4.81 & 0.38 & 0.51 & 0.36 & 0.04 & 0.003 & 0.001 & 0.0007 \\
\hline 11 & 4.78 & 2.14 & 1.82 & 2.01 & 5.82 & 9.01 & 0.68 & 0.46 & 1.13 & 0.04 & 0.006 & 0.001 & 0.0007 \\
\hline 12 & 4.66 & 2.63 & 1.49 & 2.01 & 7.29 & 6.90 & 0.57 & 0.34 & 0.80 & 0.04 & 0.005 & 0.001 & 0.0006 \\
\hline 13 & 3.41 & 4.52 & 0.86 & 1.21 & 6.12 & 3.67 & 0.55 & 0.48 & 0.75 & 0.02 & 0.003 & 0.000 & 0.0002 \\
\hline 14 & 3.0 & 5.0 & 0.74 & 0.96 & 5.07 & 4.01 & 0.49 & 0.39 & 0.61 & 0.02 & 0.003 & 0.000 & 0.0001 \\
\hline 15 & 3.36 & 2.03 & 1.91 & 2.59 & 6.64 & 4.07 & 0.55 & 0.34 & 0.74 & 0.02 & 0.003 & 0.000 & 0.0004 \\
\hline 16 & 3.55 & 2.07 & 1.59 & 2.03 & 9.90 & 6.87 & 0.40 & 0.41 & 0.39 & 0.02 & 0.002 & 0.000 & 0.0003 \\
\hline 17 & 3.53 & 1.63 & 1.54 & 2.08 & 3.53 & 7.28 & 0.88 & 0.37 & 1.89 & 0.02 & 0.005 & 0.000 & 0.0003 \\
\hline 18 & 4.03 & 3.38 & 1.69 & 2.28 & 8.51 & 10.24 & 0.61 & 0.42 & 0.93 & 0.02 & 0.002 & 0.000 & 0.0003 \\
\hline 19 & 3.83 & 1.98 & 2.22 & 1.23 & 3.85 & 2.63 & 0.47 & 0.47 & 0.55 & 0.02 & 0.005 & 0.001 & 0.0004 \\
\hline 20 & 4.10 & 1.85 & 1.05 & 1.48 & 2.45 & 4.66 & 1.00 & 0.37 & 2.47 & 0.02 & 0.008 & 0.000 & 0.0002 \\
\hline 21 & 5.76 & 4.69 & 1.22 & 1.25 & 9.01 & 5.65 & 0.40 & 0.37 & 0.39 & 0.02 & 0.002 & 0.000 & 0.0002 \\
\hline 22 & 5.31 & 5.34 & 1.21 & 1.58 & 8.23 & 3.34 & 0.42 & 0.38 & 0.43 & 0.02 & 0.002 & 0.000 & 0.0002 \\
\hline 23 & 3.25 & 5.69 & 0.71 & 1.21 & 4.11 & 3.29 & 0.49 & 0.49 & 0.59 & 0.02 & 0.004 & 0.001 & 0.0001 \\
\hline 24 & 3.48 & 2.66 & 1.56 & 2.28 & 12.76 & 4.89 & 0.41 & 0.28 & 0.41 & 0.02 & 0.001 & 0.000 & 0.0003 \\
\hline
\end{tabular}


International Advanced Research Journal in Science, Engineering and Technology

Impact Factor 7.105 Vol. 9, Issue 1, January 2022

DOI: 10.17148/IARJSET.2022.9113

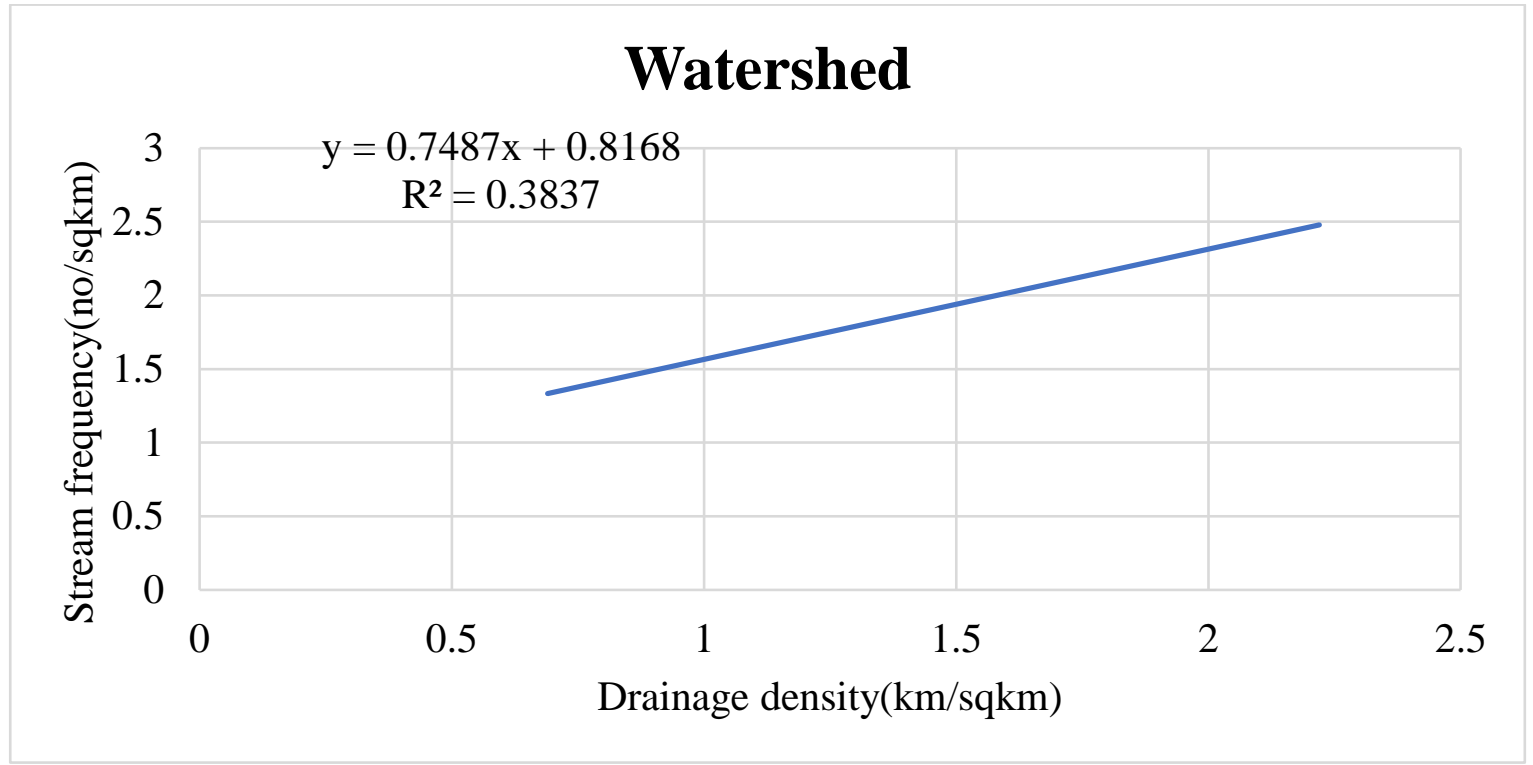

Fig. 3 Drainage density vs Stream

\subsection{CONCLUSION}

In order to understand the hydrological process of watershed, morphometric analysis is carried out at sub watershed level. Watershed is designated as $6^{\text {th }}$ order watershed. It is observed that the mean stream length of any given order is greater than that of the lower order but less than that of the next higher order. This deviation might be due to change in topographic elevation and structural disturbance. In sub watersheds 21 and 22 the bifurcation ratio is more than 5 hence it shows there is a geological disturbance. Drainage density nature is observed that very coarse to coarse textured. Stream frequency is low. The watershed is elongated to circular in shape. The higher relative relief indicates that it is composed of resistant rock patches and lower relief ratio indicates less resistant patch of rocks.

\section{REFERENCES:}

[1] Parvez, Inayathulla and Chalapathi K "Geomorphological Analysis of Two Mini Watersheds in Raichur City, Karnataka in IRJET VOL 6 ISSUE 6 JUNE 2019.

[2] Chalapathi K and Mohammed Inayathulla "Ground Water Prospects Map for SuryanagaraWatershed" in IJRIT VOL 6 ISSUE 2 JULY 2019.

[3] Chalapathi K and Mohammed Inayathulla "Estimation of crop water requirement for Kolar taluk subwatershed" in IJRIT VOL 6 ISSUE 2 JULY 2019 impact factor 5.86.

[4] Parvez, Inayathulla and Chalapathi K Analysis of Landforms of a Mini Watershed of Manvi Taluk, Raichur District Karnataka" in IJIRT Vol 6 Issue 4, September 2019 ISSN:2349-6002.

[5] Carlos Henrique Grohmann „Morphometric analysis in geographic information systems: applications of free software GRASS 2004, p1055-167.

[6] Horton R.E., "Erosional Development of Streams and their Drainage Basins, Hydro physical Approach to Quantitative Morphology", Geological Society of America Bulletin, Vol.56, 1945. p 275-370.

[7] Maria Kouli, Filippos Vallianatos,Pantelis Soupios,Dimitris Alexakis „GIS-based morphometric analysis of two major watersheds, western Crete, Greecee Jan 2007.

[8] Nageshwara Rao.K, Swarna Latha.K, Arun Kumar.P, Harikrishna.M, (2010), "Morphometric Analysis of Gostani River Basin in Andhra Pradesh State, India Using Spatial Information Technology.” International Journal of Geomatics and Geosciences, Vol.1, 179-187 